\title{
The influence of nutritional conditions on metal uptake by the mixotrophic dual symbiosis harboring vent mussel Bathymodiolus azoricus
}

\author{
Inês Martins ${ }^{\mathrm{a},{ }^{*},}$, Raul Bettencourt ${ }^{\mathrm{a}}$, Ana Colaço ${ }^{\mathrm{a}}$, Pierre-Marie Sarradin ${ }^{\mathrm{b}}$, Ricardo Serrão Santos ${ }^{\mathrm{a}}$ and \\ Richard Cosson ${ }^{\mathrm{C}}$
}

\footnotetext{
a IMAR, DOP-Department of Oceanography and Fisheries, University of the Azores, 9901-862 Horta, Portugal

${ }^{\mathrm{b}}$ Ifremer Centre de Brest, Département Etudes des Ecosystèmes Profond, BP70, F-29280 Plouzané, France

c Université de Nantes, Laboratoire de Biologie Marine, ISOMer, MMS, BP 92208, 44322 Nantes, France
}

\footnotetext{
* Corresponding author : I. Martins, Tel.: + 351 292200457; fax: + 351 292200411, email address : imartins@uac.pt
}

\begin{abstract}
:
The vent mussel Bathymodiolus azoricus, host thioautotrophic and methanotrophic bacteria, in their gills and complementary, is able to digest suspended organic matter. But the involvement of nutritional status in metal uptake and storage remains unclear. The influence of $B$. azoricus physiological condition on its response to the exposure of a mixture of metals in solution is addressed. Mussels from the Menez Gwen field were exposed to $50 \mu \mathrm{g} \mathrm{L}^{-1} \mathrm{Cd}$, plus $25 \mu \mathrm{g} \mathrm{L}^{-1} \mathrm{Cu}$ and $100 \mu \mathrm{g} \mathrm{L}^{-1} \mathrm{Zn}$ for 24 days. Four conditions were tested: (i) mussels harboring both bacteria but not feed, (ii) harboring only methanotrophic bacteria, (iii) without bacteria but fed during exposure and (iv) without bacteria during starvation. Unexposed mussels under the same conditions were used as controls. Eventual seasonal variations were assessed. Metal levels were quantified in subcellular fractions in gills and digestive gland. Metallothionein levels and condition indices were also quantified. Gill sections were used for fluorescence in situ hybridization (FISH) to assess the temporal distribution of symbiotic associations. Starvation damages metal homeostasis mechanisms and increase the intracellular $\mathrm{Zn}$ and MT levels function. There is a clear metallic competition for soluble and insoluble intracellular ligands at each condition. Seasonal variations were observed at metal uptake and storage.
\end{abstract}

Keywords: Vent mussel B. azoricus; Metal accumulation; Nutritional condition; Metallothioneins; Condition indices 


\section{Introduction}

The mytilid mussel, Bathymodiolus azoricus, is one of the dominant hydrothermal vent macroorganisms in the Azores Triple Junction region, distributed at depths ranging from $840 \mathrm{~m}$ (Menez Gwen vent field) to $2300 \mathrm{~m}$ (Rainbow vent field) ([Colaço et al., 1998] and [Desbruyères et al., 2001]). This hydrothermal vent mussel is a mixotrophic organism whose energy is obtained by 1) dual endosymbiosis, based on both thioautotrophic (SOX) and methanotrophic (MOX) bacteria within gill bacteriocytes ([Fiala-Médioni et al., 2002] and Duperron et al., 2006 S. Duperron, C. Bergin, F. Zielinski, A. Blazejak, A. Pernthaler, Z.P. McKiness, E. DeChaine, C.M. Cavanaugh and N. Dubilier, A dual symbiosis shared by two mussel species, Bathymodiolus azoricus and Bathymodiolus puteoserpentis (Bivalvia: Mytilidae), from hydrothermal vents along the northern Mid-Atlantic Ridge, Environ Microbiol 8 (2006), pp. 1441-1447. Full Text via CrossRef | View Record in Scopus | Cited By in Scopus (43)[Duperron et al., 2006]), and 2) suspension-feeding, through well developed labial palps and a functional feeding tract, which allow B. azoricus to filter and digest organic matter particles ([Le Pennec et al., 1990] and [Page et al., 1991]). Both nutritional pathways allow $\mathrm{B}$. azoricus to colonize environments where the availability of substrates is unpredictable or fluctuating (Salerno et al., 2005). B. azoricus relies mostly on the primary production of the symbionts for its nutritional requirements ([Salerno et al., 2005] and [De Busserolles et al., 2009]). Suspension-feeding, a secondary mode of nutrition ([Colaço et al., 2009], [De Busserolles et al., 2009] and [Riou et al., 2010]), works as an additional nutritional strategy according to external concentrations of hydrogen sulfide (H2S) and methane (CH4) (Martins et al., 2008). The hydrothermal fluid provides to the vent fauna not only necessary energy sources and suspension organic particles, but also potentially toxic compounds such as metals ([Desbruyères et al., 2000], [Douville et al., 2002] and [Kádár et al., 2005a]). Nevertheless, hydrothermal vent mussels developed mechanisms enabling the detoxification of metals, like their storage under insoluble granules or their binding to specific metalloproteins, namely metallothioneins (Cosson and Vivier, 1995). Several studies have shown the ability of B. azoricus to accumulate large amounts of metals from their environment ([Kádár et al., 2005b], [Cosson et al., 2008] and [Martins et al., 2009]) but the 
62 role of the trophic pathway in their uptake is still not clear. In the present study, the

63 accumulation of two essential $(\mathrm{Cu}$ and $\mathrm{Zn})$ and one non essential $(\mathrm{Cd})$ metals, was

64 followed in the gills and the digestive gland of B. azoricus, maintained under various

65 conditions susceptible to modify their physiological status. Our protocols were designed

66 in order to show eventual differences in the uptake and bioaccumulation of these three

67 metals when mussels rely on (i) both symbionts, (ii) only methanotrophic symbionts, (iii)

68 supplied organic food, as energy source or (iv) are starving.

\section{Material and Methods}

\subsection{Sample collection and maintenance}

Acoustically retrievable cages were moored during the MoMARETO cruise (with the French R/V "Pourquoi Pas?") in August-September 2006. They were positioned on diffuse venting areas at Menez Gwen hydrothermal field (37 $\left.51^{\prime} \mathrm{N} ; 31^{\circ} 31^{\prime} \mathrm{W}\right)$ and filled with approximately 400 mussels using the Ifremer Remotely Operated Vehicle (ROV) "Victor 6000". Our experiments were performed on mussels from Menez Gwen collected during MoMARETO cruise (brought to the surface using the ROV and designated hereafter as "Summer mussels"), and from two cages recovered by the Portuguese R/V

81 "Arquipélago" in January and May 2007 (designated hereafter as "Winter mussels" and

82 "Spring mussels", respectively). Specimens from Menez Gwen hydrothermal field were 83 chosen for the experiments, because this field is the shallowest one of the Azores Triple 84 Junction (ATJ) and mussels can survive and maintain their endosymbionts active at 85 atmospheric pressure (Kádár et al. 2005a, Bettencourt et al. 2008, Company et al. 2008, 86 Riou et al. 2008). Once the mussels were brought to the surface, they were immediately 87 transferred to fresh cooled seawater and held in plastic cool boxes during transit to a land88 based refrigerated laboratory "LabHorta" (environment temperature $8-11^{\circ} \mathrm{C}$ (Colaço \& 89 Santos 2002)). In the laboratory, 8 groups of 27 mussels of comparable sizes (summer: 45 $90 \pm 7 \mathrm{~mm}$, winter: $46 \pm 5 \mathrm{~mm}$, spring: $46 \pm 5 \mathrm{~mm}$ ) were cleaned of visible adhering 91 material. Each group was kept in $10 \mathrm{~L}$ plastic containers filled with $8-9^{\circ} \mathrm{C}$ seawater 92 (warmer water was found to inactivate methane oxidizers in the vent mussel 
93 Bathymodiolus childressi (Kochevar et al. 1992)) and air-oxygen supply, for laboratory

94 acclimatization before metal exposures. Seawater for the containers was supplied from a

95 reservoir containing sand-filtered seawater from an unpolluted bay in Horta, Azores

$96\left(38^{\circ} 58^{\prime} \mathrm{N} ; 28^{\circ} 78^{\prime} \mathrm{W}\right)$ (Cruz et al. 2010). Water conditions (temperature, $\mathrm{pH}$ and $\mathrm{O}_{2}$

97 saturation) were daily monitored (table 1).

\subsection{Experimental protocols}

101 The following procedure was undertaken for each of the 3 type of seasonal mussels.

102 Protocol (i): mussels harboring both symbiont bacteria and not fed

103 Mussels were kept in plain seawater with no gas or food supply, for a concomitant

104 symbiont bacteria mislay, and exposed to the metal mixture after 3 days of laboratory 105 acclimatization.

106 Protocol (ii): mussels harboring only methanotrophic bacteria

107 Mussels were kept in seawater enriched only by bubbling ultra-pure $\mathrm{CH}_{4}(\mathrm{~N} 45$, Air-

108 Liquide), during 3 weeks, for thiotrophic bacteria loss prior to their exposure to the metal

109 mixture and during the exposure. Since high methane concentrations, above $300 \mu \mathrm{M}$,

110 were found inhibitory for symbionts of the vent mussel B. childressi exhibiting high

111 methane consumption rates (Kochevar et al. 1992), we tried to maintain $\mathrm{CH}_{4}$

112 concentration below this level $(20-50 \mu \mathrm{M})$. The dissolved $\mathrm{CH}_{4}$ in water was monitored

113 daily (table 1) by sampling $50 \mathrm{~mL}$ of seawater in a $500 \mathrm{~mL}$ bottle which was rolled for 20

114 minutes before measuring the headspace $\mathrm{CH}_{4}$ with a portable GMI Gasurveyor 500 .

115 Protocol (iii): mussels without symbiont bacteria but supplied with food

116 Mussels were kept in methane- and sulfide-free seawater during 3 weeks for both

117 symbiotic bacteria loss prior to their exposure to the metal mixture. Before and during 118 exposure, the mussels were fed with a concentrate solution $\left(6 \times 10^{10}\right.$ cell/liter $)$ of 119 microalgae Nannochloropsis

120 Protocol (iv): mussels without symbiont bacteria and not fed

121 Mussels were kept in methane- and sulfide-free seawater during 3 weeks for both 122 symbiotic bacteria loss prior to their exposure to the metal mixture. 
126 The 4 groups from the initial 8 groups were maintained for 24 days in sea water 127 containing $50 \mu \mathrm{g} \mathrm{L}^{-1} \mathrm{Cd}\left(\mathrm{Cd}\left(\mathrm{NO}_{3}\right)_{2}\right.$, Merck, CertiPur $\left.{ }^{\circledR}\right)$, plus $25 \mu \mathrm{g} \mathrm{L}^{-1} \mathrm{Cu}\left(\mathrm{Cu}(\mathrm{NO} 3)_{2}\right.$, 128 Merck, CertiPur ${ }^{\circledR}$ ) and plus $100 \mu \mathrm{g} \mathrm{L}^{-1} \mathrm{Zn}$ (Zn (NO3)2, Merck, CertiPur $\left.{ }^{\circledR}\right)$. The 129 concentrations of added metals were selected according to Company (2005) who handled 130 several experiments with metals on B. azoricus. The remained 4 groups of 27 mussels 131 were maintained following similar protocols ( $\mathrm{i}$ to iv) but without the addition of metal 132 mixture and were used as controls. Water was renewed every 3 days to eliminate organic 133 matter that could result in oxygen depletion, and maintain a $\mathrm{pH}$ of 7-8. Food and metals 134 were added to renewed water. No sulfide was added in the water during the exposure to 135 prevent the precipitation of metals. Before the first addition of metals 6 mussels 136 (designated hereafter as "day 0") were sampled from each protocol. Then 6 mussels were 137 sampled from each protocol at days 6, 15 and 24 of the exposure. As well, 6 mussels 138 (designated hereafter as "control mussels") were sampled at days 15 and 24 from each 139 control protocol. From each sampled individual, shell length was recorded and gills and 140 digestive gland tissues were dissected and preserved at $-80^{\circ} \mathrm{C}$ until freeze-drying. Metals 141 and metallothioneins analysis were performed in both tissues.

\subsection{Metal analyses}

145 Approximately $100 \mathrm{mg}$ of dry tissue were homogenized in TRIS buffer (100 mM, $10 \mathrm{mM}$ 146 B-mercaptoethanol, $\mathrm{pH} 8.6)$ and centrifuged $\left(30000 \mathrm{~g}, 30 \mathrm{~min}, 4^{\circ} \mathrm{C}\right)$. For each sample, the 147 pellet containing the insoluble compounds (designated hereafter as "insoluble fraction") 148 and an aliquot $(2 \mathrm{ml})$ of the supernatant, containing the soluble compounds (designated 149 hereafter as "soluble fraction") were digested with nitric acid (65\% v/v, Merck, p.a.) at 150 room temperature during 12 hours follow by a 2 hours heat-bath at $60^{\circ} \mathrm{C}$. After pellets 151 and supernatant digestion, solutions were dried at $60^{\circ} \mathrm{C}$ and solubilized by adding $2 \mathrm{ml}$ $1520.5 \mathrm{~N} \mathrm{HNO}_{3} . \mathrm{Cd}, \mathrm{Cu}$ and $\mathrm{Zn}$ were determined by flame atomic absorption 153 spectrophotometry (GBC-Avanta $\Sigma$ ), with deuterium background correction, or graphite 154 furnace atomic absorption spectrometry (Perkin-Elmer, Zeeman 4110ZL) depending on 
155 metal levels. The accuracy and precision of the method used were established by regular 156 analysis of certified reference materials, mussel tissue CE278 (European Reference 157 Materials of Belgium) and lobster hepatopancreas TORT-2 (National Research Council 158 of Canada). Certified reference materials and blanks were taken through the procedure in 159 the same way as the samples. Our values and the certified values are given in Table 2 as $160 \mu \mathrm{g} \mathrm{g}^{-1}$ of dry weight.

\subsection{Metallothioneins (MT)}

164 To determine MT level, an aliquot of the supernatant from the centrifugation described 165 above was heat-denatured $\left(90^{\circ} \mathrm{C}, 15 \mathrm{~min}\right)$ and centrifuged at $13000 \mathrm{~g}, 10 \mathrm{~min}$, at $4^{\circ} \mathrm{C}$. In 166 the heat-denatured supernatant the amount of MT was determined by Differential Pulse 167 Polarography (DPP) according to Olafson and Sim (1979) and Thompson and Cosson 168 (1984). A standard addition calibration curve was obtained using rabbit liver MT-I as 169 reference. Results were expressed as $\mu \mathrm{g} \mathrm{g}^{-1}$ of dry weight. Olafson and Olsson (1991) 170 have confirmed, by quantitative analyses on chromatographic fractions, that the method is 171 specific for MT after removal of contaminating proteins in tissue homogenates by heat 172 denaturation. The contribution of the mercaptoethanol and the low-molar-mass 173 compounds (such as glutathione and free cysteins) during MT quantification is negligible 174 (Olafson \& Sim 1979, Geret \& Cosson 2002).

\subsection{Condition Indices}

178 Tissue condition index (TCI) and gill index (GI) were used to assess the mussel 179 physiological condition before (day 0) and during the exposure period. The measure of 180 both indices in mussels at day 0 will represent their status after acclimatization and before 181 exposure.

182 The tissue condition index was calculated as follows:

$183 \mathrm{TCI}=$ tissues dry weight $(\mathrm{g}) /$ shell volume $(\mathrm{ml})($ Voets et al. 2006)

184 The mussel volume (Mv) was calculated based on the length of the mussel with the 185 formula: $\mathrm{M}_{\mathrm{v}}=(\text { length })^{\mathrm{a}}$ 
186 This allometric relationship was determined empirically as follows. The shell volume of

$187127 \mathrm{~B}$. azoricus with a length between 25 and $97 \mathrm{~mm}$ was measured with graduated 188 cylinders (to the nearest $0.5 \mathrm{ml}$ ) using the Archimeds Principle. The length of the mussel

189 was plotted against the shell volume and a power relation was calculated $\left(\mathrm{R}^{2}=0,984\right.$;

$190 \mathrm{p}<0,01$ ) with allometric exponent (a) equal to 2,719 (unpublished data).

191 The gill index was calculated as follows:

$192 \mathrm{GI}=($ gill tissue dry weight $(\mathrm{g}) /$ shell volume $(\mathrm{ml})) \times 10$

\subsection{Fluorescence in situ-hybridization (FISH)}

To check the presence or absence of symbionts in B. azoricus, according to each experiment protocol, gill tissues of 1 mussel was dissected for FISH analysis at 0 and 24 days. Analyses were performed according to Duperron (2005) with slight modifications.

199 Gill tissues were dissected immediately after removing mussels from the aquaria, preserved in $10 \%$ buffered formalin and processed for paraffin embedding according to standard protocol. Transverse sections ( $7 \mu \mathrm{m}$ thick) were subjected to deparafinization and re-hydration through successive baths of xylene, ethanol $(100 \%, 95 \%$ and $70 \%$

203 respectively) and rinsed with distilled water. Before hybridization, the sections were 204 incubated in a pre-hybridization solution for $5 \mathrm{~min}$ at $46^{\circ} \mathrm{C}$. The hybridization reaction 205 was carried out at $46^{\circ} \mathrm{C}$ for $4 \mathrm{~h}$ with a hybridization solution containing the specific 206 bacteria probes, individualized by a circle of PAP pen. After incubation, the sections 207 were placed $15 \mathrm{~min}$ in a washing solution. The Alexa Fluo-488 208 GCTCCGCCACTAAGCCTA and Alexa Fluo-532 CGAAGGTCCTCCACTTTA 209 fluorescent probes were used to target respectively thiotrophic and methanotrophic 210 symbionts (Duperron et al. 2005, Bettencourt et al. 2008). The fluochromes Alexa 488 211 and Alexa 532 were from Molecular Probes, Invitrogen. Gill filaments were visualized 212 under fluorescent light and differential interference contrast (DIC) microscopy using a 213 Leica DM6000 digital microscope (Leica Microsystems CMS GmbH, Germany). Results 214 are presented in Figure. 6 
218 Data were first tested for normality by normal probability plots and the homogeneity of

219 variances was checked using Bartlett's test. Since data did not respect the assumptions of 220 analysis of variance, the reciprocal square-root (sqrt) transformation $[1 /$ sqrt $(x+0,5)]$ was 221 applied. Analyses of covariance (ANCOVA) and one-way ANOVA were used on 222 transformed data to evaluate the variability between groups of samples. Tukey's test was 223 used as post hoc comparison of means. Sperman rank correlations were used to evaluate 224 the relation between the levels of MT and metals associated with soluble compounds 225 measured in both exposed mussels organs. Tests were performed with STATISTICA 6.0 226 (StatSoft). Differences were considered significant when $\mathrm{p}<0,05$. Statistical methods 227 were selected in accordance with Zar (1999).

\section{Results}

\subsection{Water conditions and mortality}

The measured water parameters (temperature, $\mathrm{pH}, \mathrm{O}_{2}$ and dissolved $\mathrm{CH}_{4}$ ) did not show

234 variations in each protocol between the collection seasons, therefore Table 1 represents 235 the mean values measured at the three collection seasons.

236 Mortality was recorded at summer season in protocol (ii), with 16\% in exposed group and $2377 \%$ in control group and in protocol (iv), with $4 \%$ of mortality record in exposed group.

238 In winter, 7\% of mortality was recorded in exposed group of protocol (ii).

\subsection{Metal accumulation}

242 Mean metal levels in the gills and the digestive gland of control and exposed mussels, 243 following the protocols at the 3 seasons, are shown in Figures 1 to 3. 
248 For the 24 days of exposure, whatever the experimental protocol or season, a similar

249 bioaccumulation pattern was observed, resulting from significant increases of Cd levels

250 (ANOVA, $\mathrm{p}<0,05$ ). On the contrary, the levels in control mussels remained constantly

251 low with the exception of some erratic values noticed at the three seasons for protocol (i).

252 In non-exposed mussels $\mathrm{Cd}$ was preferably associated to insoluble compounds (Table 3 ).

253 Whatever the experimental protocol or season the subcellular distribution of $\mathrm{Cd}$ did not

254 change, Cd remained preferably associated to insoluble compounds.

255 Digestive Gland (Figures 1, d-e-f)

256 For the 24 days of exposure, whatever the experimental protocol or season, a similar

257 bioaccumulation pattern was observed, resulting from significant increases of Cd levels

258 (ANOVA, $\mathrm{p}<0,05$ ). On the contrary, the levels in control mussels remained constantly 259 low with the exception of non significant values noticed after 24 days in summer for 260 protocols (i) and in spring (iv) (ANOVA, p>0,05). In non-exposed mussels $\mathrm{Cd}$ was 261 equally distributed between soluble and insoluble fractions whatever the season (Table 262 3). The ratio of $\mathrm{Cd}$ bioaccumulated under soluble forms increased when mussels were 263 submitted to protocol (i) in summer and winter. The opposite was observed with protocol 264 (ii) with $\mathrm{Cd}$ preferably bioaccumulated under insoluble forms. For both protocols, in 265 spring, bioaccumulated $\mathrm{Cd}$ remained equally distributed.

\subsubsection{Copper}

269 Gills (Figures 2, a-b-c)

$270 \mathrm{Cu}$ levels were generally higher in exposed mussels than in control mussels (ANOVA, $271 \mathrm{p}<0,05$ ) with few exceptions at day 24 for protocol (i) in summer and for protocol (ii) in 272 winter. $\mathrm{Cu}$ bioaccumulation patterns varied with season for a same experimental protocol 273 with maximum $\mathrm{Cu}$ levels reached by day 24 being lower in winter than in summer or 274 spring (ANCOVA, $\mathrm{p}<0.05$ ). Whatever the experimental protocol or season the 275 subcellular distribution of $\mathrm{Cu}$ did not change, $\mathrm{Cu}$ remained preferably associated to 276 soluble compounds (Table 3).

277 Digestive Gland (Figures 2, d-e-f) 
278 Whatever the experimental protocol and season, $\mathrm{Cu}$ levels in exposed mussels were not 279 significant different from levels in control mussels (ANOVA, p>0,05) with few 280 exceptions at day 24 for protocol (i) at the 3 seasons, at day 24 for protocol (ii) in summer 281 and at day 15 for protocol (ii) in spring (ANOVA, $\mathrm{p}<0,05$ ). Whatever the experimental 282 protocol or season the subcellular distribution of $\mathrm{Cu}$ did not change, $\mathrm{Cu}$ remained 283 preferably associated to soluble compounds (Table 3). After 24 days of exposure the 284 bioaccumulation of $\mathrm{Cu}$ seems to be more intensive in the gills than in the digestive gland, 285 especially following the protocol (iv).

Gills (Figures 3, a-b-c)

290 Whatever the experimental protocol and season, there was no clear evidence of $\mathrm{Zn}$ 291 bioaccumulation in the gills of exposed mussels compared to controls. In summer $\mathrm{Zn}$ was equally distributed between soluble and insoluble compounds at the subcellular level in non-exposed mussels (Table 3). After exposures using the protocols (iii) and (iv), Zn shifted to the soluble compartment. In winter and spring, $\mathrm{Zn}$ was preferably associated to soluble compounds in non-exposed mussels and this distribution did not change except in winter after exposures using the (i) and (ii) protocols leading to an equal distribution of

300 Zn levels in control mussels were uniform only for mussels collected in spring, while in

301 summer and winter levels varied whatever the experimental protocol with extreme values 302 reached at day 24 at protocol (iv). A part from the equal distribution of $\mathrm{Zn}$ in non303 exposed mussels from summer, $\mathrm{Zn}$ was preferably associated to soluble compounds 304 whatever the experimental protocol or season (Table 3). In summer and winter the 305 variations of $\mathrm{Zn}$ levels were more intense in the digestive gland than in the gills for 306 corresponding experimental protocols and exposure duration. In spring, no obvious

307 differences were observed between the variations of $\mathrm{Zn}$ levels in gills and digestive 308 gland. 
311 Gills (Figures 4, a-b-c)

312 The mean level of MT in controls (whatever the experimental protocol, season or

313 collection day) was $2052 \pm 613\left(\mu \mathrm{gg}^{-1}\right)$ with exceptional values noticed in protocol (i) in

314 summer and in protocol (iv) in winter. No common trend could be observed for a given

315 experimental protocol regarding the pattern of MT level variations with seasons.

316 Generally, MT levels of exposed mussels were not significantly different from control

317 mussel levels (ANOVA, $\mathrm{p}>0,05)$.

318 Digestive Gland (Figures 4, d-e-f)

319 MT levels varied a lot in control mussels in summer and winter whatever the

320 experimental protocol. In spring the levels were lower (ANOVA, $\mathrm{p}<0.05$ ) and their 321 variation was less important. Mean levels of MT in mussels exposed in winter under 322 protocols (ii), (iii) and (iv) were higher than the levels reached for the same protocols in 323 summer and spring (ANCOVA, $\mathrm{p}<0.05$ ).

\subsection{TCI and GI}

327 The mean values of tissue condition index (TCI) and gill index (GI) in non-exposed (day

328 0) and exposed mussels collected at the 3 seasons are shown in Figure 5.

329 TCI (Figures 5, a-b-c):

330 At day 0 TCI did not showed significant variation between experimental protocols in 331 summer and spring (ANOVA, $\mathrm{p}>0.05$ ). In winter, TCI at day 0 was significantly higher 332 for protocols (i) and (ii) (ANOVA, $\mathrm{p}<0.05$ ). Whatever the experimental protocol and 333 season, there was no significant variation of mean TCI during 24 days for exposed 334 mussels (ANOVA, $\mathrm{p}>0.05$ ). Between seasons, whatever the experimental protocol, 335 mussels collected in summer showed significant lower TCI (ANCOVA, p<0.05). 336 Moreover, for protocol (iii) and (iv) mussels collected in spring showed significant higher 337 TCI (ANCOVA, p<0.05).

338 GI (Figures 5, d-e-f): 
339 At day 0 whatever the season, GI did not show significant variation between 340 experimental protocols (ANOVA, $\mathrm{p}>0.05$ ). Whatever the experimental protocol, there 341 was no significant variation of mean GI during 24 days for exposed mussels (ANOVA, $342 \mathrm{p}>0.05$ ) in summer and spring. In winter, a significant decrease of GI was observed after 343 day 6 for protocol (iii) (ANOVA, $\mathrm{p}<0.05$ ). Whatever the experimental protocol or season, 344 control mussels did not show any variation during the experimental period (ANOVA, $345 \mathrm{p}>0.05$ ). Between seasons, whatever the experimental protocol, mussels collected in 346 summer showed significant lower GI (ANCOVA, $\mathrm{p}<0.05$ ).

350 The images of the detection of thioautotrophic and methanotrophic bacteria in the gill 351 tissue are shown in Figure 6. No difference was found in bacterial densities between the 352 mussels collected at the 3 seasons. Therefore, the panels contain the representative 353 images of bacteria densities found at the beginning (day 0 ) and by the end (day 24) of 354 each exposure protocol.

\section{Protocol (i)}

356 The gill tissues were taken from the fresh mussels immediately after their arrival at the

357 laboratory, therefore bacterial detection at day 0 corresponds to the natural abundance of 358 endosymbionts (A1). The fluorescent probes detected both thioautotrophic (red) and 359 methanotrophic (green) bacteria. After 24 days of exposure (A2), the density of 360 thioautotrophic bacteria was rather low and the gill filaments showed empty 361 bacteriocytes. The methanotrophic bacteria were not detected anymore.

362 Protocol (ii)

363 The gill tissues, at day 0 , were taken from mussels acclimatized during 3 weeks in plain 364 sea water supplied with $\mathrm{CH}_{4}$. The fluorescent probes detected the methanotrophic (green) 365 bacteria distributed at the bacteriocytes boundary (B1). After 24 days of exposure (B2), 366 methanotrophic bacteria were rather detected and gill filaments showed empty 367 bacteriocytes.

\section{Protocol (iii) and (iv)}


369 The gill tissues, at day 0, were taken from mussels acclimatized during 3 weeks in plain 370 sea water. Both bacteria were rather detected or undetected (C1). After 24 days of

371 exposure (C2) no bacteria was detected. Nevertheless, gill filaments showed the presence 372 of hemocytes.

\section{Discussion}

Several reasons are responsible for the choice of B. azoricus as an experimental model for understanding how its physiological functioning manages metal bioaccumulation and storage. (a) The amount of data regarding the relationships of bivalves and metals present in their environment is extensive (Viarengo \& Nott 1993, Langston et al. 1998, Company 2005, Wang \& Rainbow 2005) (b) Bathymodiolus genus is present at most of the known chemosynthesis-based ecosystems. (c) As other species, B. azoricus relies on mixotrophy for its nutrition by ways of dual symbiosis (MOX and SOX bacteria). (d) B. azoricus abundance at moderate depth sites on Menez Gwen MAR-ATJ field allows its maintenance at atmospheric pressure in suitable devices (Colaço \& Santos 2002). Recently special attention was devoted to study the effects of metals $(\mathrm{Cu}, \mathrm{Cd})$ on the antioxidant defense system of $B$. azoricus and concomitant neosynthesis of metallothioneins (Company et al. 2008, Company et al. 2010). At the moment no data are available regarding this species about the combined effects and the bioaccumulation of a

389 mixture of metals. However in situ B. azoricus are exposed simultaneously and 390 continuously to several metals under dissolved and particle form (Sarradin et al. 1999, 391 Sarradin et al. 2008). In spite of our current knowledge on uptake of metals by $B$. 392 azoricus, an evaluation is still lacking on the relative importance of the nutritional 393 pathway versus the direct uptake by diffusion into the organs in contact with the 394 surrounding water. Our work was devised in order to meet the exposure to a mixture of 395 metals $(\mathrm{Cd}, \mathrm{Cu}, \mathrm{Zn})$ during four physiological conditions, in combination with $B$. 396 azoricus food source. They relied as food source, at the beginning of the exposure, on the 397 presence of both SOX and MOX bacteria in the gills (i). They relied as food source on 398 the sole presence of MOX bacteria that were supplied with methane during the exposure 399 (ii). They did not harbor any kind of symbiotic bacteria but were provided with 
400 microalgae during the exposure (iii). They did not harbor any kind of symbiotic bacteria 401 and were not given any food supply (iv). It was shown that metal bioaccumulation could

402 be influenced by the season in relation with the reproductive cycle (Langston et al. 1998).

403 To take into account this biotic factor, our experiments were performed on mussels

404 collected during summer, winter and spring that correspond respectively to sexual pause,

405 spawning period and spawning recovery as shown by Colaço et al. (2006).

\subsection{Mussel physiological status}

The lower TCI and GI found in mussels collected in summer could be a consequence of a 410 stress linked to animal collection using the ROV. In opposition to a cage recovery in 411 which mussels arrive to the surface in approximately 20 minutes, a submersible recovery 412 may take hours inflicting a decompression physiological stress difficult to recover (Dixon 413 et al. 2004, Pruski \& Dixon 2007). Results from FISH showed that even with methane 414 supply the MOX bacteria disappeared from mussel gills by the end of the $24^{\text {th }}$ day of 415 exposure to the metal's mixture. Experimental research developed by Kochevar et al. 416 (1992) on Bathymodiolus sp. showed that optimal rates of methane consumption by 417 methanotrophic symbionts bacteria are reached when methane is supplied at 418 concentrations ranging from $150-350 \mu \mathrm{M}$. In our study we supplied the mussels with 419 methane concentrations ranging 20-50 $\mu \mathrm{M}$. Kochevar et al. (1992) showed that at low 420 methane concentrations mussel metabolic functions seem decreasing, including lower 421 rates of oxygen and methane consumption. At similar methane conditions, low rates of 422 carbon incorporation in gills were evidenced by Riou et al. (2008). The mussel low 423 metabolism and a consequent increase of maintenance requirements can result in a low 424 TCI (De Coen \& Janssen 2003).

425 Exposed mussels fed with microalgae, collected in spring, showed high TCI. We can 426 assume that feeding exposed B. azoricus with microalgae at this time of the year 427 improves a little bit their physiological status or limits its deterioration. Moreover, 428 phytoplanktonic fatty acid biomarkers were detected in B. azoricus, from Menez Gwen, 429 collected in May (Pond et al. 1998, Colaço et al. 2009) indicating a potential use of 430 suspension-feeding on particles sedimenting from the sea surface at this season (Riou 
431 2009). Is noteworthy the ability of $B$. azoricus to survive under starvation conditions, 432 metal exposure and endosymbionts loss. Similar to coastal mussels, B. azoricus present 433 storage cells in mantle connective tissue and gills (such as the hemocytes observed), 434 enriched with lipids and glycogen that allow the specie to survive if their nutrition is 435 affected by the loss of the symbiotic bacteria (Lobo-da-Cunha et al. 2006, Bettencourt et 436 al. 2008). 4.2. Metal uptake and storage

442 In the gills where metals can be uptake directly from the medium $\mathrm{Cd}$ and $\mathrm{Cu}$ were 443 bioaccumulated between day 0 and day 24 while $\mathrm{Zn}$ levels remained stable. The 444 bioaccumulation of $\mathrm{Cd}$ and $\mathrm{Cu}$ from water in the gills was already shown in coastal 445 mussels by several authors (Carpené \& George 1981, Geret 2000, Isani et al. 2000) with 446 the respective involvements of $\mathrm{Ca}^{++}$or $\mathrm{Na}^{+}$channels. Whatever the season, exposed and 447 non exposed mussels harboring both bacteria showed a highly variable $\mathrm{Cd}$ and $\mathrm{Cu}$ 448 accumulation. That can reflect changes in their physiological system due to mislay of 449 bacteria during the 24 days. $\mathrm{Zn}$ is not bioaccumulated when mussels are fed with 450 microalgae while an increase of $\mathrm{Zn}$ levels is observed in summer, when they are starving. 451 The observed increases of $\mathrm{Zn}$ levels following starvation may likely be explained by the 452 dysfunction of internal metal regulatory mechanisms as a consequence of starvation. A 453 preferential storage of $\mathrm{Cd}$ in association with insoluble compounds was observed while $454 \mathrm{Cu}$ was preferably stored in association with soluble forms. Company et al. (2008) and 455 (2010) exposed B. azoricus to the same concentrations of $\mathrm{Cd}$ and $\mathrm{Cu}$, under similar 456 conditions of maintenance, however not simultaneously. After 24 days of exposure both 457 bioaccumulated $\mathrm{Cd}$ and $\mathrm{Cu}$ were stored preferably in association with soluble compounds 458 in the gills. We can hypothesize that the competition between $\mathrm{Cd}$ and $\mathrm{Cu}$ for soluble 459 ligands favored $\mathrm{Cu}$ and resulted in $\mathrm{Cd}$ binding to insoluble compounds. The important 460 contribution of organelles and lysosomes to $\mathrm{Cd}$ detoxication has been mentioned earlier 461 by Viarengo and Nott (1993). Cd binding as insoluble form in the gills, which are in 
462 direct contact with the external medium, brings advantages since it could reduce $\mathrm{Cd}$ 463 cellular toxicity and may eventually facilitate its excretion by exocytosis (Langston et al.

464 1998). On the other hand, the sequestration of $\mathrm{Cd}$ under insoluble forms may result from 465 saturation or damages of the mechanisms involved in $\mathrm{Cd}$ storage under soluble forms as 466 mentioned by (Company et al. 2006, Choi et al. 2007). Copper, bioaccumulated in 467 association with soluble compounds, was the unique metal that could induce the 468 neosynthesis of MTs. As almost no increase of MT levels were observed, we can assume 469 that accumulated $\mathrm{Cu}$ in the soluble compartment was bound to existing MTs as the result 470 of substitution to MT constitutive Zn or Cd (Langston et al. 1998). Zinc intracellular level 471 is regulated with an equal distribution between soluble and insoluble associated 472 compounds and a tendency to favor the association with soluble compounds. We can 473 assume that in our experimental conditions B. azoricus was able to reduce the uptake of 474 zinc from gill surrounding medium and regulate its storage or excretion as shown 475 previous for coastal mussels (Anandraja et al. 2002, Kondoh et al. 2003, Wang \& 476 Rainbow 2005). The bioaccumulation of $\mathrm{Zn}$ as soluble form in mussels under starvation 477 is likely to participate to MT level increases in summer and winter. But as shown earlier 478 by several authors the increases of MT levels may also be attributed to a global stress 479 reaction to starvation (Cosson 2000, Viarengo et al. 2000, Kondoh et al. 2003).

\subsubsection{Digestive gland}

483 In general Cd was bioaccumulated with an equal distribution between the soluble and the 484 insoluble compartment, or rather preferably associated to soluble compounds. In the 485 coastal mussel Mytilus galloprovincialis, collected in a highly $\mathrm{Cd}$ contaminated area, a 486 very important accumulation of $\mathrm{Cd}$ was observed in the digestive gland (Raspor et al. 487 1999). Whatever the season or protocol $\mathrm{Cu}$ was preferably associated to soluble 488 compounds. The same preference was also mentioned by Geret (2000) for the coastal 489 mussel Mytilus edulis experimentally exposed to $\mathrm{Cu}$. At all seasons a increase of MT 490 levels was observed in the digestive gland by the end of the exposures. This increase of 491 MT levels by the end of the exposures may be related to the binding of bioaccumulated $492 \mathrm{Cd}$ to soluble compounds. The association of the bioaccumulated $\mathrm{Cd}$ to insoluble 
493 compounds as an explanation to the lack of increase of MT levels was already pointed out

494 above for the gills. Such increases of MT levels following Cd exposures of coastal 495 mussels were observed previous and attributed to $\mathrm{Cd}$ bioaccumulation as soluble forms 496 (Raspor et al. 1999, Geret 2000). Mussels with both bacteria as food source showed a 497 correlation between soluble $\mathrm{Cu}$ and MT levels at all seasons (Table 4). Moreover, several 498 correlations were established between soluble Zn and MT levels whatever the protocol 499 used, but significant correspondent increases of MT levels were not noticed underlining 500 the complexity of MT synthesis regulation in B. azoricus (Hardivillier et al. 2004, 501 Company et al. 2006, Martins et al. 2009).

503 In summary, the use of exposures to a mixture of metals was designed to approach 504 mussel in situ conditions. Nevertheless, we can not neglect the fact that during the 24 505 days exposure a modification of the ratio: number of mussels/metal availability occurs, 506 which may occasionally increase the levels of metals by the end of the exposure. Our 507 results regarding the distribution of $\mathrm{Cd}$ at the subcellular level were not in accordance 508 with previous results obtained after mono-metallic exposures of B. azoricus or coastal 509 mussels. In addition, the observed $\mathrm{Cd}$ preferential storage as insoluble forms in the gills 510 comes into conflict with data from in situ collected B. azoricus. These discrepancies may 511 be explained by several factors (a) the use of metal concentrations higher than that 512 measured in B. azoricus surrounding environment (b) in the mixture, metals were in 513 solution while in situ they are present under both dissolved and particulate forms (c) in a 514 mixture, metals compete for their uptake and storage by the exposed organisms contrarily 515 to what happens when a mono-metallic exposure is used. However, our results show that 516 B. azoricus is able to adapt its metal handling strategies to versatile close environment 517 conditions. It underlines the $B$. azoricus ability to store metals (here $\mathrm{Cd}$ ) under insoluble 518 forms preventing potential toxic impacts. We put forward that B. azoricus metal uptake 519 and storage mechanisms are similar to those already described for coastal mussels which 520 are highly influenced by metallic ions size and electronic affinity for cellular compounds. 521 Comparing our results with the reproductive cycle of B. azoricus, described earlier by 522 Colaço et al. (2006), the influence of reproductive status, on metal uptake and storage 523 does not appear clearly despite observed seasonal variations. Further work is needed to 
524 establish the existence of a relationship similar to that observed for coastal bivalves. 525 Regarding the impact of the nutritional status of exposed B. azoricus on the handling of 526 added dissolved metals we confirm that starvation results in a dysfunction of metal 527 homeostasis mechanisms with an increase of intracellular Zn and MT levels. We also 528 show that, when $B$. azoricus relies solely on its alimentation through its functional 529 digestive tract (microalgae supply) metal uptake and storage regulation mechanisms are 530 still efficient to prevent the dysfunction of essential metal homeostasis. The ability of $B$.

531 azoricus endosymbionts bacteria to survive in starvation conditions, under experimental 532 conditions, was described earlier (Kádár et al. 2005a, Colaço et al. 2006, Bettencourt et 533 al. 2008). Experiments performed under improved exposure and nutritional conditions are 534 needed to go further in our knowledge of metal uptake routes bioaccumulation and 535 regulation in B. azoricus.

537 The authors gratefully acknowledge the captain and crew of the R/V "Pourquoi Pas?" and 538 Victor 6000 ROV team, during the MOMARETO cruise (IFREMER). The captain and 539 crew of the R/V “Arquipélago". Joana Raimundo, Rute Cesário, Carmelina Leal, Luis 540 Pires, Domitília Rosa and Carla Dâmaso for the greatest contribution in the laboratory 541 work. DRCT M2.1.1/I/008/2005 - LabHorta - Automation and Up-Grading of LabHorta542 Technology for the exploration of marine molecules of deep-sea organisms (PRODESA). 543 The EU research project EXOCET/D, FP6-GOCE-CT-2003-505342, the Portuguese 544 Science Foundation funded program SEAHMA project (FCT/ PDCTM 545 1999/MAR/15281), the IMUNOVENT project (PTDC/MAR/65991/2006), the 546 Pluriannual and Programmatic funding from FCT and DRCT for research unit \#531 and 547 LA \#9, Camões Institution- Pessoa program (GRICES/FCT). I. Martins works under a 548 FCT PhD grant (SFRH/BD/19736/2004)

\section{5. References}

552 Anandraja A, Marshall DJ, Gregory MA, McClurg TP (2002) Metal accumulation, 553 filtration and $\mathrm{O}_{2}$ uptake rates in the mussel Perna perna (Mollusca: Bivalvia) 
exposed to $\mathrm{Hg}^{2+}, \mathrm{Cu}^{2+}$ and $\mathrm{Zn}^{2+}$. Comparative Biochemistry and Physiology 132:355-363

556 Bettencourt R, Dando P, Rosa D, Riou V, Colaco A, Sarrazin J, Sarradin PM, Santos RS (2008) Changes of gill and hemocyte-related bio-indicators during long term

Carpené E, George SG (1981) Absorption of cadmium by gills of Mytilus edulis (L.). Molecular Physiology 1:23-34

Choi HJ, Ji J, Chung KH, Ahn IY (2007) Cadmium bioaccumulation and detoxification in the gill and digestive gland of the Antarctic bivalve Laternula elliptica. Comparative Biochemistry and Physiology C-Toxicology \& Pharmacology $145: 227-235$

Colaço A, Desbruyères D, Comtet T, Alayse A-M (1998) Ecology of the Menez Gwen hydrothermal vent field (Mid-Atlantic Ridge/Azores Triple Junction). Cahiers de Biologie Marine 39:237-240

Colaço A, Martins I, Laranjo M, Pires L, Leal C, Prieto C, Costa V, Lopes H, Rosa D, Dando PR, Serrão-Santos R (2006) Annual spawning of the hydrothermal vent mussel, Bathymodiolus azoricus, under controlled aquarium conditions at atmospheric pressure. Journal of Experimental Marine Biology and Ecology 333:166-171

Colaço A, Prieto C, Martins A, Figueiredo M, Lafon V, Monteiro M, Bandarra NM (2009) Seasonal variations in lipid composition of the hydrothermal vent mussel Bathymodiolus azoricus from the Menez Gwen vent field. Marine Environmental Research 67:146-152

Colaço A, Santos RS (2002) LABHORTA, a land-based laboratory for vent studies, in towards planning of sea-floor observatory programs for the MAR region In: Santos RS, Escartin, J., Colaço, A., and Adamczewska, A. (ed) II MoMAR Workshop. Arquipélago, Life and Marine Sciences

Company R (2005) Antioxidant defense systems in the deep-sea mussel Bathymodiolus azoricus from Mid-Atlantic Ridge hydrothermal vents. University of Algarve 
584 Company R, Serafim A, Cosson R, Fiala-Médioni A, Camus L, Colaço A, Santos R, Bebianno M (2008) Antioxidant biochemical responses to long-term copper exposure in Bathymodiolus azoricus from Menez-Gwen hydrothermal vent. Science of the Total Environment:407-417

Company R, Serafim A, Cosson R, Fiala-Médioni A, Camus L, Santos R, Bebianno M (2010) Sub-lethal effects of cadmium on the antioxidant defense system of the hydrothermal vent mussel Bathymodiolus azoricus. Ecotoxicology and Environmental Safety

Company R, Serafim A, Cosson R, Fiala-Médioni A, Dixon D, Bebianno MJ (2006) Temporal variation in the antioxidant defense system and lipid peroxidation in the gills and mantle of hydrothermal vent mussel Bathymodiolus azoricus. Deep-Sea Research Part a-Oceanographic Research Papers 53:1101-1116

Cosel R, Comtet T, Krylova EM (1999) Bathymodiolus (Bivalvia: Mytilidae) from hydrothermal vents on the Azores Triple Junction and the Logatchev hydrothermal hield, Mid-Atlantic Ridge. The Veliger 42:218-248

Cosson RP (2000) Bivalve metallothionein as a biomarker of aquatic ecosystem pollution by trace metals: Limits and perspectives. Cellular and Molecular Biology 46:295309

Cosson RP, Thiebaut E, Company R, Castrec-Rouelle M, Colaço A, Martins I, Sarradin PM, Bebianno MJ (2008) Spatial variation of metal bioaccumulation in the hydrothermal vent mussel Bathymodiolus azoricus. Marine Environmental Research 65:405-415

Cosson RP, Vivier JP (1995) Impact of metals on hydrothermal vent communities: bioaccumulation and detoxication processes. Marine Environmental Research 39:349

Cruz JV, Pacheco D, Cymbron R, Mendes S (2010) Monitoring of the groundwater chemical status in the Azores archipelago (Portugal) in the context of the EU water framework directive. Environ Earth Sci 61:173-186

De Busserolles F, Sarrazin J, Gauthier O, Gelinas Y, Fabri MC, Sarradin PM, Desbruyeres D (2009) Are spatial variations in the diets of hydrothermal fauna 
linked to local environmental conditions? Deep-Sea Research Part Ii-Topical Studies in Oceanography 56:1649-1664

616 De Coen WM, Janssen CR (2003) The missing biomarker link: Relationships between

617 effects on the cellular energy allocation biomarker of toxicant-stressed Daphnia magna and corresponding population characteristics. Environmental Toxicology and Chemistry 22:1632-1641

Desbruyères D, Almeida A, Biscoito M, Comtet T, Khripounoff A, Le Bris N, Sarradin PM, Segonzac M (2000) A review of the distribution of hydrothermal vent communities along the northern Mid-Atlantic Ridge: dispersal vs. environmental controls. Hydrobiologia 440:201-216

Desbruyères D, Biscoito M, Caprais JC, Colaço A, Comtet T, Crassous P, Fouquet Y, Khripounoff A, Le Bris N, Olu K, Riso R, Sarradin PM, Segonzac M, Vangriesheim A (2001) Variations in deep-sea hydrothermal vent communities on the Mid-Atlantic Ridge near the Azores plateau. Deep-Sea Research Part 48:13251346

Dixon DR, Pruski AM, Dixon LRJ (2004) The effects of hydrostatic pressure change on DNA integrity in the hydrothermal-vent mussel Bathymodiolus azoricus: implications for future deep-sea mutagenicity studies. Mutation ResearchFundamental and Molecular Mechanisms of Mutagenesis 552:235-246

Douville E, Charlou JL, Oelkers EH, Bienvenu P, Colon CFJ, Donval JP, Fouquet Y, Prieur D, Appriou P (2002) The Rainbow vent fluids (36 degrees 14 ' N, MAR): the influence of ultramafic rocks and phase separation on trace metal content in Mid-Atlantic Ridge hydrothermal fluids. Chemical Geology 184:37-48

Duperron S, Bergin C, Zielinski F, Blazejak A, Pernthaler A, McKiness ZP, DeChaine E, Cavanaugh CM, Dubilier N (2006) A dual symbiosis shared by two mussel species, Bathymodiolus azoricus and Bathymodiolus puteoserpentis (Bivalvia : Mytilidae), from hydrothermal vents along the northern Mid-Atlantic Ridge. Environmental Microbiology 8:1441-1447

Duperron S, Nadalig T, Caprais JC, Sibuet M, Fiala-Medioni A, Amann R, Dubilier N (2005) Dual symbiosis in a Bathymodiolus sp. mussel from a methane seep on the gabon continental margin (southeast Atlantic): 16S rRNA phylogeny and 
distribution of the symbionts in gills. Applied and Environmental Microbiology 71:1694-1700

Fiala-Médioni A, McKiness ZP, Dando P, Boulegue J, Mariotti A, Alayse-Danet AM, immunological characterization of two populations of the mytilid mussel Bathymodiolus azoricus from the Mid-Atlantic Ridge: evidence for a dual symbiosis. Marine Biology 141:1035-1043

Geret F (2000) Synthèse de métallothionéines chez deux bivalves (l'huître et la moule) en réponse à une contamination métallique par la voie directe et par la voie trophique. Université de Nantes

Geret F, Cosson RP (2002) Induction of specific isoforms of metallothionein in mussel tissues after exposure to cadmium or mercury. Archives of Environmental Contamination and Toxicology 42:36-42

Hardivillier Y, Leignel V, Denis F, Uguen G, Cosson R, Laulier M (2004) Do organisms living around hydrothermal vent sites contain specific metallothioneins? The case of the genus Bathymodiolus (Bivalvia, Mytilidae). Comparative Biochemistry and Physiology Part C 139:111-118

Isani G, Andreani G, Kindt M, Carpene E (2000) Metallothioneins (MTs) in marine molluscs. Cellular and Molecular Biology 46:311-330

Kádár E, Bettencourt R, Costa V, Santos RS, Lobo-da-Cunha A, Dando P (2005a) Experimentally induced endosymbiont loss and re-acquirement in the hydrothermal vent bivalve Bathymodiolus azoricus. The Journal of Experimental Biology

Kádár E, Costa V, Martins I, Santos S, Powell J (2005b) Enrichment in trace metals (Al, $\mathrm{Mn}, \mathrm{Co}, \mathrm{Mo}, \mathrm{Cd}, \mathrm{Fe}, \mathrm{Zn}, \mathrm{Pb}$ and $\mathrm{Hg}$ ) of macro-invertebrate habitats at hydrothermal vents along the Mid-Atlantic Ridge. Hydrobiologia 548:191-205

Kochevar RE, Childress JJ, Fisher CR, Minnich E (1992) The methane mussel- roles of symbiont and host in the metabolic utilization of methane. Marine Biology $112: 389-401$ 
674 Kondoh M, Imada N, Kamada K, Tsukahara R, Higashimoto M, Takiguchi M, Watanabe Y, Sato M (2003) Property of metallothionein as a Zn pool differs depending on the induced condition of metallothionein. Toxicology Letters 142:11-18

Langston WJ, Bebianno MJ, Burt G (1998) Metal handling strategies in molluscs. In: Langston WJ, Bebianno, M.J. (ed) Metal Metabolism in Aquatic Environments. Chapmann \& Hall, London, p 219-284

Le Pennec M, Donval A, Herry A (1990) Nutritional strategies of the hydrothermal ecosystem bivalves. Progress in Oceanography 24:71-80

Lobo-da-Cunha A, Kadar E, Santos RS (2006) Histochemical and ultrastructural characterisation of mantle storage cells in the hydrothermal-vent bivalve Bathymodiolus azoricus. Marine Biology 150:253-260

Martins I, Colaço A, Dando PR, Martins I, Desbruyeres D, Sarradin PM, Marques JC, Serrao-Santos R (2008) Size-dependent variations on the nutritional pathway of Bathymodiolus azoricus demonstrated by a C-flux model. Ecological Modelling 217:59-71

Martins I, Colaço A, Santos RS, Lesongeur F, Godfroy A, Sarradin PM, Cosson RP (2009) Relationship between the occurrence of filamentous bacteria on Bathymodiolus azoricus shell and the physiological and toxicological status of the vent mussel. Journal of Experimental Marine Biology and Ecology 376:1-6

Olafson RW, Olsson PE (1991) Electrochemical detection of metallothionein. Methods in Enzymology 205:205-213

Olafson RW, Sim RG (1979) Electrochemical approach to quantification and characterization of metallothioneins. Analytical Biochemistry 100:343-351

Page H, Fiala-Medioni A, Fisher C, Childress J (1991) Experimental evidence for filterfeeding by the hydrothermal vent mussel, Bahymodiolus thermophilus. Deep-sea Research 38:1455-1461

Pond DW, Bell MV, Dixon DR, Fallick AE, Segonzac M, Sargent JR (1998) Stablecarbon-isotope composition of fatty acids in hydrothermal vent mussels containing methanotrophic and thiotrophic bacterial endosymbionts. Applied and Environmental Microbiology 64:370-375 
704 Pruski AM, Dixon DR (2007) Heat shock protein expression pattern (HSP70) in the hydrothermal vent mussel Bathymodiolus azoricus. Marine Environmental Research 64:209-224

Raspor B, Erk M, Pavicic J, Juric D, Kwokal Z, Odzak N (1999) Metallothionein as biomarker of mussel exposure to heavy metals. In: IAEA-TEC-DOC1094 (ed) Marine Pollution Symposium, Monaco, p 151-156

Riou V (2009) Nutritional plasticity in a deep-sea dual-endosymbiotic suspension-feeding mussel: Bathymodiolus azoricus from MAR hydrothermal vents. Vrije Universiteit Brussel

Riou V, Colaço A, Bouillon S, Khripounoff A, Dando P, Mangion P, Chevalier E, Korntheuer M, Santos RS, Dehairs F (2010) Mixotrophy in the deep sea: a dual endosymbiotic hydrothermal mytilid assimilates dissolved and particulate organic matter. Marine Ecology Progress Series 405:187-201

Riou V, Halary S, Duperron S, Bouillon S, Elskens M, Bettencourt R, Santos RS, Dehairs F, Colaco A (2008) Influence of $\mathrm{CH}_{4}$ and $\mathrm{H}_{2} \mathrm{~S}$ availability on symbiont distribution, carbon assimilation and transfer in the dual symbiotic vent mussel Bathymodiolus azoricus. Biogeosciences 5:1681-1691

Salerno JL, Macko SA, Hallam SJ, Bright M, Won Y-J, McKiness Z, Van Dover CL (2005) Characterization of symbiont populations in life-history stages of mussels from chemosynthetic environments. Biological Bulletin 208:145-155

Sarradin P-M, Caprais J-C, Riso R, Kerouel R, Aminot A (1999) Chemical environment of the hydrothermal mussel communities in the Lucky Strike and Menez Gwen vent fields, Mid Atlantic Ridge. Cahiers de Biologie Marine 40:93-104

Sarradin PM, Lannuzel D, Waeles M, Crassous P, Le Bris N, Caprais JC, Fouquet Y, Fabri MC, Riso R (2008) Dissolved and particulate metals (Fe, $\mathrm{Zn}, \mathrm{Cu}, \mathrm{Cd}, \mathrm{Pb}$ ) in two habitats from an active hydrothermal field on the EPR at 13 degrees $\mathrm{N}$. Science of the Total Environment 392:119-129

Thompson JAJ, Cosson RP (1984) An improved electrochemical method for the quantification of metallothioneins in marine organisms. Marine Environmental Research 11:137-152 
Viarengo A, Burlando B, Ceratto N, Panfoli I (2000) Antioxidant role of metallothioneins: A comparative overview. Cellular and Molecular Biology 46:407-417

Viarengo A, Nott JA (1993) Mechanisms of heavy metal cation homeostasis in marine

Voets J, Talloen W, de Tender T, van Dongen S, Covaci A, Blust R, Bervoets L (2006)

Zar JH (1999) Biostatistical Analysis, Vol. Prentice-Hall New Jersey

Fig. 2- Mean variation of $\mathrm{Cu}$ levels ( $\mu \mathrm{g} \mathrm{g}^{-1}$, dry weight) in the gills (a-b-c) and digestive 
766 Fig. 3- Mean variation of $\mathrm{Zn}$ levels ( $\mu \mathrm{g} \mathrm{g}^{-1}$, dry weight) in the gills (a-b-c) and digestive 767 gland (d-e-f) of control (dashed lines) and exposed mussels (solid lines) at each 768 experiment (i, ii, iii, iv) for 24 days.

770 Fig. 4- Mean variation of MT levels ( $\mu \mathrm{g} \mathrm{g}^{-1}$, dry weight) in the gills (a-b-c) and digestive 771 gland (d-e-f) of control (dashed lines) and exposed mussels (solid lines) at each 772 experiment (i, ii, iii, iv) for 24 days.

774 Fig. 5- Mean variation $\left(\mathrm{g} \mathrm{ml}^{-1}\right)$ of TCI (a-b-c) and GCI (d-e-f) of control (dashed lines) 775 and exposed mussels (solid lines) at each experiment (i, ii, iii, iv) for 24 days.

778 Fig.6. Detection of thiotrophic and methanotrophic bacterial endosymbionts in gills 779 tissue. Fluorescent probes were used to target thiotrophic (red) and methanotrophic 780 (green) bacterial symbionts in fluorescence in-situ hybridization (FISH) experiments. 781 Differential interference contrast (DIC) visualization is shown (right side of panels). 782 Scale bar $(10 \mu \mathrm{m})$ and original objective magnifications are indicated. Panel A shows the 783 density of both bacteria at day 0 (A1) and day 24 (A2) of exposure for experiment (i). 784 Panel B shows the methanotrophic bacteria density at day 0 (B1) and day 24 (B2) of 785 exposure for experiment (ii). Panel $\mathrm{C}$ shows the density of both bacteria at day $0(\mathrm{C} 1)$ and 786 day 24 (C2) of exposure for experiment (iii) and (iv). 
Table 1

Mean water conditions for the three collection seasons at each experiment (i; ii; iii; iv) for exposed and control mussels. Results as mean \pm SD; $n=$ 123.

\begin{tabular}{ccccc}
\hline experiment & $\begin{array}{c}\text { Temperature } \\
\left({ }^{\circ} \mathrm{C}\right)\end{array}$ & $\mathrm{pH}$ & $\begin{array}{c}\mathrm{O}_{2} \text { saturation } \\
(\%)\end{array}$ & $\begin{array}{c}\text { Dissolved CH4 } \\
(\mu \mathrm{M})\end{array}$ \\
\hline i & $8.7 \pm 1.1$ & $8.0 \pm 0.2$ & $59.7 \pm 7.5$ & - \\
control & $8.7 \pm 1.1$ & $8.1 \pm 0.2$ & $60.1 \pm 9.7$ & - \\
ii & $9.1 \pm 0.9$ & $8.1 \pm 0.3$ & $53.9 \pm 11.1$ & $41.2 \pm 25.0$ \\
control & $9.1 \pm 0.9$ & $8.2 \pm 0.2$ & $55.5 \pm 10.3$ & $33.5 \pm 17.8$ \\
iii & $8.9 \pm 1.0$ & $8.2 \pm 0.2$ & $58.3 \pm 9.1$ & - \\
control & $8.9 \pm 1.0$ & $8.0 \pm 0.7$ & $55.5 \pm 8.4$ & - \\
iv & $8.9 \pm 1.0$ & $8.2 \pm 0.2$ & $55.9 \pm 6.6$ & - \\
control & $8.9 \pm 0.9$ & $8.1 \pm 0.2$ & $59.3 \pm 9.6$ & - \\
\hline
\end{tabular}

Table 2

Levels of $\mathrm{Cd}, \mathrm{Cu}$ and $\mathrm{Zn}$ found in certified reference material, mussel tissue CE278 (ERM-Belgium) and lobster hepatopancreas TORT-2 (NRCCCanada). Results as mean $\pm \mathrm{SD}$, in $\mu \mathrm{g} \mathrm{g}^{-1}$ dry weight.

\begin{tabular}{|c|c|c|c|}
\hline Certified & $\mathrm{Cd}\left(\mu \mathrm{g} \mathrm{g}^{-1}\right)$ & $\mathrm{Cu}\left(\mu \mathrm{g} \mathrm{g}^{-1}\right)$ & $\mathrm{Zn}\left(\mu \mathrm{g} \mathrm{g}^{-1}\right)$ \\
\hline $\begin{array}{l}\text { reference } \\
\text { material }\end{array}$ & $\mathrm{n}=21$ & $\mathrm{n}=30$ & $\mathrm{n}=15$ \\
\hline
\end{tabular}




\begin{tabular}{lllll}
\hline & Observed & - & - & $83.8 \pm 2.5$ \\
TORT-2 & Certified & $26.7 \pm 0.6$ & $106 \pm 10$ & - \\
& Observed & $25.6 \pm 1.2$ & $105 \pm 6$ & - \\
\hline
\end{tabular}

\section{Table 3}

Amounts of metals associated with insoluble compounds (expressed as percentages- mean \pm SD ) in the gill and digestive gland tissues of nonexposed (ne) (mussels from day 0) and exposed mussels for each experiment (i; ii; iii; iv), collected in summer, winter and spring.

\begin{tabular}{r|ll|ll|ll} 
& Summer & & Winter & & \multicolumn{2}{l}{ Spring } \\
\hline & G & GD & G & GD & G & GD \\
\hline ne & $86 \pm 5$ & $46 \pm 14$ & $58 \pm 26$ & $59 \pm 21$ & $80 \pm 10$ & $57 \pm 8$ \\
i & $64 \pm 11$ & $30 \pm 11$ & $54 \pm 12$ & $29 \pm 8$ & $77 \pm 9$ & $56 \pm 8$ \\
ii & $73 \pm 8$ & $65 \pm 12$ & $73 \pm 8$ & $61 \pm 14$ & $77 \pm 8$ & $46 \pm 9$ \\
iii & $80 \pm 6$ & $53 \pm 14$ & $80 \pm 8$ & $56 \pm 12$ & $73 \pm 9$ & $51 \pm 6$ \\
iv & $64 \pm 14$ & $58 \pm 16$ & $58 \pm 15$ & $57 \pm 11$ & $84 \pm 4$ & $55 \pm 8$ \\
\hline Cu & & & & & & \\
ne & $61 \pm 11$ & $45 \pm 13$ & $35 \pm 7$ & $26 \pm 8$ & $47 \pm 4$ & $21 \pm 4$
\end{tabular}




\begin{tabular}{r|ll|ll|ll} 
i & $37 \pm 13$ & $30 \pm 9$ & $34 \pm 7$ & $30 \pm 10$ & $44 \pm 7$ & $21 \pm 4$ \\
ii & $31 \pm 7$ & $30 \pm 8$ & $29 \pm 6$ & $26 \pm 9$ & $44 \pm 9$ & $16 \pm 5$ \\
iii & $34 \pm 5$ & $26 \pm 12$ & $34 \pm 4$ & $19 \pm 8$ & $43 \pm 6$ & $19 \pm 5$ \\
iv & $40 \pm 7$ & $27 \pm 8$ & $35 \pm 6$ & $21 \pm 7$ & $43 \pm 6$ & $19 \pm 5$ \\
\hline Zn & & & & & & \\
ne & $52 \pm 17$ & $53 \pm 15$ & $29 \pm 18$ & $26 \pm 13$ & $28 \pm 14$ & $33 \pm 9$ \\
i & $53 \pm 7$ & $38 \pm 9$ & $51 \pm 7$ & $37 \pm 9$ & $39 \pm 3$ & $41 \pm 3$ \\
ii & $43 \pm 6$ & $37 \pm 8$ & $46 \pm 11$ & $36 \pm 11$ & $42 \pm 4$ & $32 \pm 4$ \\
iii & $17 \pm 5$ & $25 \pm 8$ & $18 \pm 5$ & $21 \pm 7$ & $13 \pm 2$ & $23 \pm 6$ \\
iv & $17 \pm 6$ & $11 \pm 6$ & $16 \pm 7$ & $13 \pm 8$ & $13 \pm 3$ & $25 \pm 4$ \\
\hline
\end{tabular}

Table 4

Values of Spearman rank $r$ correlations between MT and metals associated with soluble compounds in gill (G) and digestive gland (DG) of mussels collected at the three seasons (summer, winter and spring) and exposed to each experiment (i, ii, iii, iv). In superscript allied $p$ values are present (n.s.: not significant; *: $\mathrm{p}<0.05$; non superscript: $\mathrm{p}=0.05$; -: metal associated with insoluble compounds)

\begin{tabular}{l|ll|ll}
\hline & $\mathrm{G}$ & & DG & \\
\hline Summer & $\mathrm{Cu}$ & $\mathrm{Zn}$ & $\mathrm{Cu}$ & $\mathrm{Zn}$ \\
\cline { 3 - 5 } & & &
\end{tabular}




\begin{tabular}{ll|cc|ll}
\hline & i & $-0.16^{\text {n.s. }}$ & - & $0.79^{*}$ & $0.73^{*}$ \\
& ii & $-0.13^{\text {n.s. }}$ & $0.18^{\text {n.s. }}$ & $0.50^{*}$ & $0.61^{*}$ \\
& iii & $0.25^{\text {n.s. }}$ & $0.39^{\text {n.s. }}$ & $0.57^{*}$ & $0.48^{*}$ \\
& iv & $0.10^{\text {n.s. }}$ & $0.42^{*}$ & $0.36^{\text {n.s. }}$ & $0.20^{\text {n.s. }}$ \\
& & & & & \\
Winter & i & $-0.26^{\text {n.s. }}$ & - & $0.70^{*}$ & $0.64^{*}$ \\
& ii & $-0.10^{\text {n.s. }}$ & $-0.21^{\text {n.s. }}$ & $0.28^{\text {n.s. }}$ & $0.47^{*}$ \\
& iii & $0.27^{\text {n.s. }}$ & $0.45^{*}$ & $0.10^{\text {n.s }}$ & $0.27^{\text {n.s. }}$ \\
& iv & $0.18^{\text {n.s. }}$ & $0.10^{\text {n.s. }}$ & $0.62^{*}$ & $0.30^{\text {n.s. }}$ \\
& & & & & \\
& i & $-0.01^{\text {n.s. }}$ & $0.12^{\text {n.s. }}$ & $0.75^{*}$ & $0.63^{*}$ \\
& ii & $0,50^{*}$ & $0.71^{*}$ & $0.33^{\text {n.s. }}$ & $0.72^{*}$ \\
& iii & $0.54^{*}$ & $0.11^{\text {n.s. }}$ & $0.65^{*}$ & $0.69^{*}$ \\
& iv & $0.47^{*}$ & 0.43 & $0.25^{\text {n.s. }}$ & $0.43^{*}$ \\
\hline
\end{tabular}




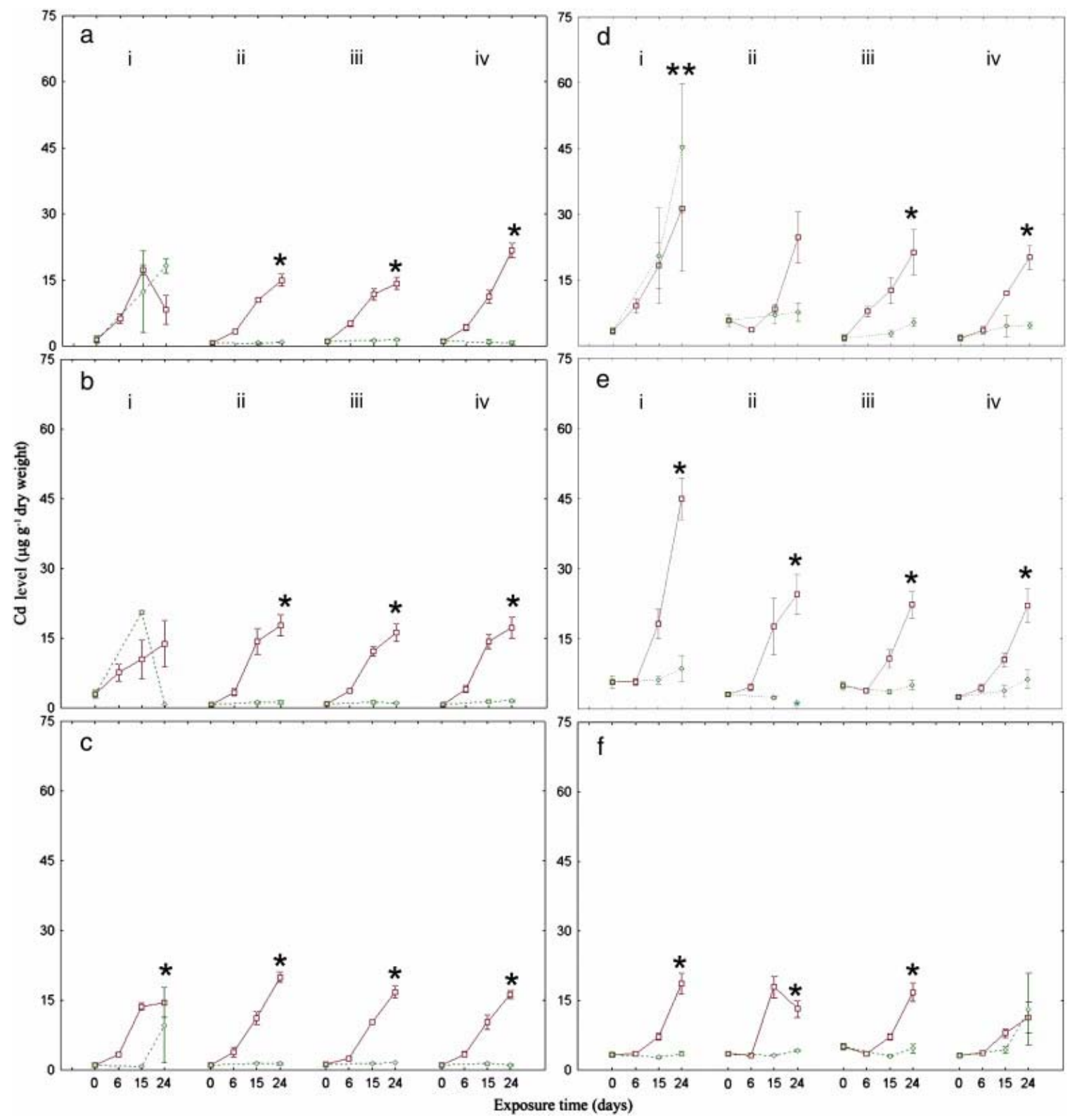

Fig. 1. Mean variation of $\mathrm{Cd}$ levels ( $\mu \mathrm{g} \mathrm{g}^{-1}$, dry mass) in the gills (a-b-c) and digestive gland ( $\mathrm{d}-$ e-f) of control (dashed lines) and exposed mussels (solid lines) at each experiment (i, ii, iii, and iv) for 24 days. Here and in [Fig. 2], [Fig. 3], [Fig. 4] and [Fig. 5], panels (a) and (d) represent the experiments undertaken in summer, (b) and (e) represent the experiments undertaken in winter and (c) and ( $f$ ) the experiments undertaken in spring. Vertical bars represent the standard error of the mean. Symbol $\left.{ }^{*}\right)$ represents significant differences between day 0 and day 24 of exposure. Symbol $\left({ }^{*}\right)$ represents significant differences between day 0 and day 24 of control. 


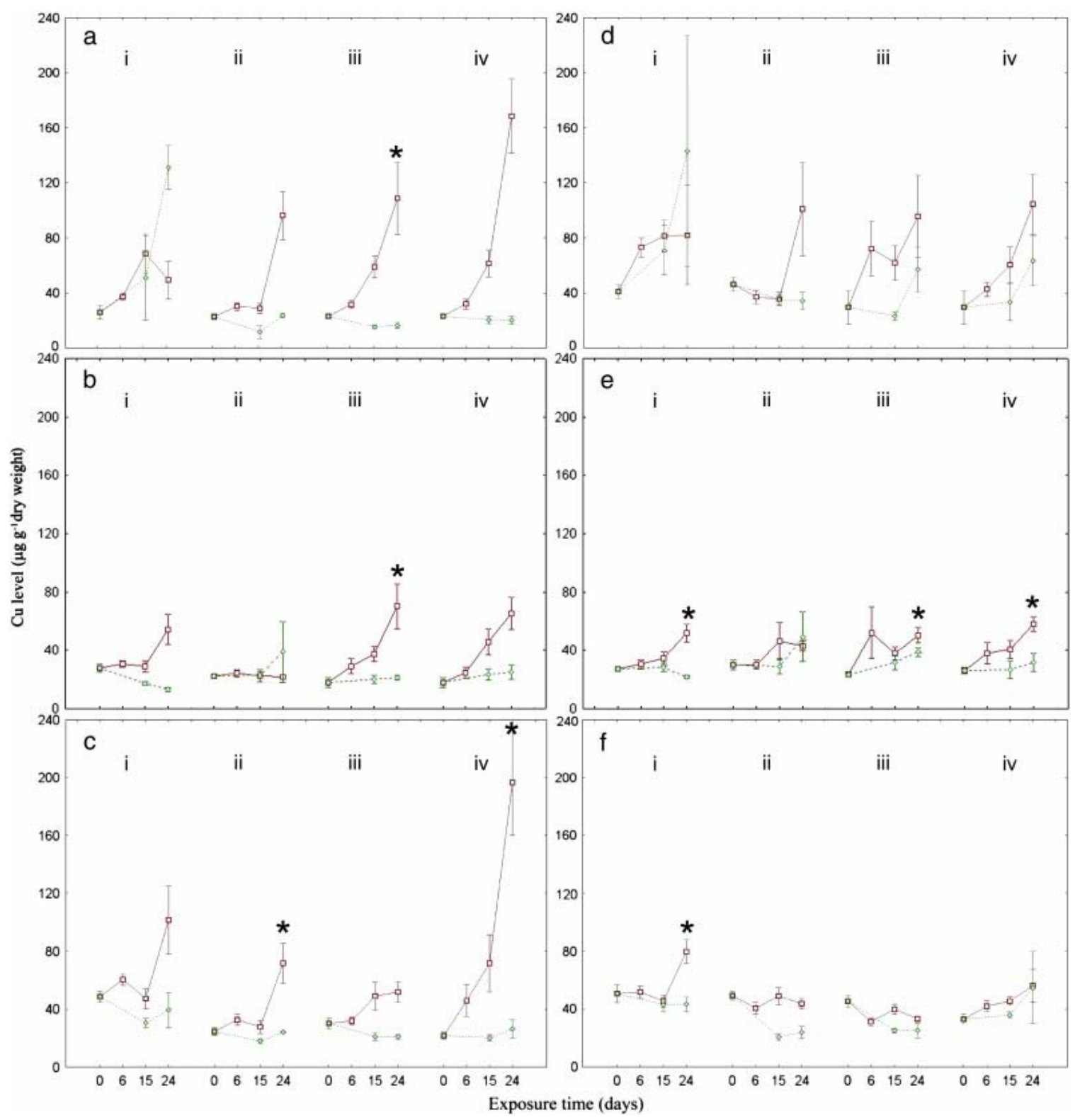

Fig. 2. Mean variation of $\mathrm{Cu}$ levels ( $\mu \mathrm{g} \mathrm{g}^{-1}$, dry mass) in the gills (a-b-c) and digestive gland (de-f) of control (dashed lines) and exposed mussels (solid lines) at each experiment (i, ii, iii, and iv) for 24 days. 


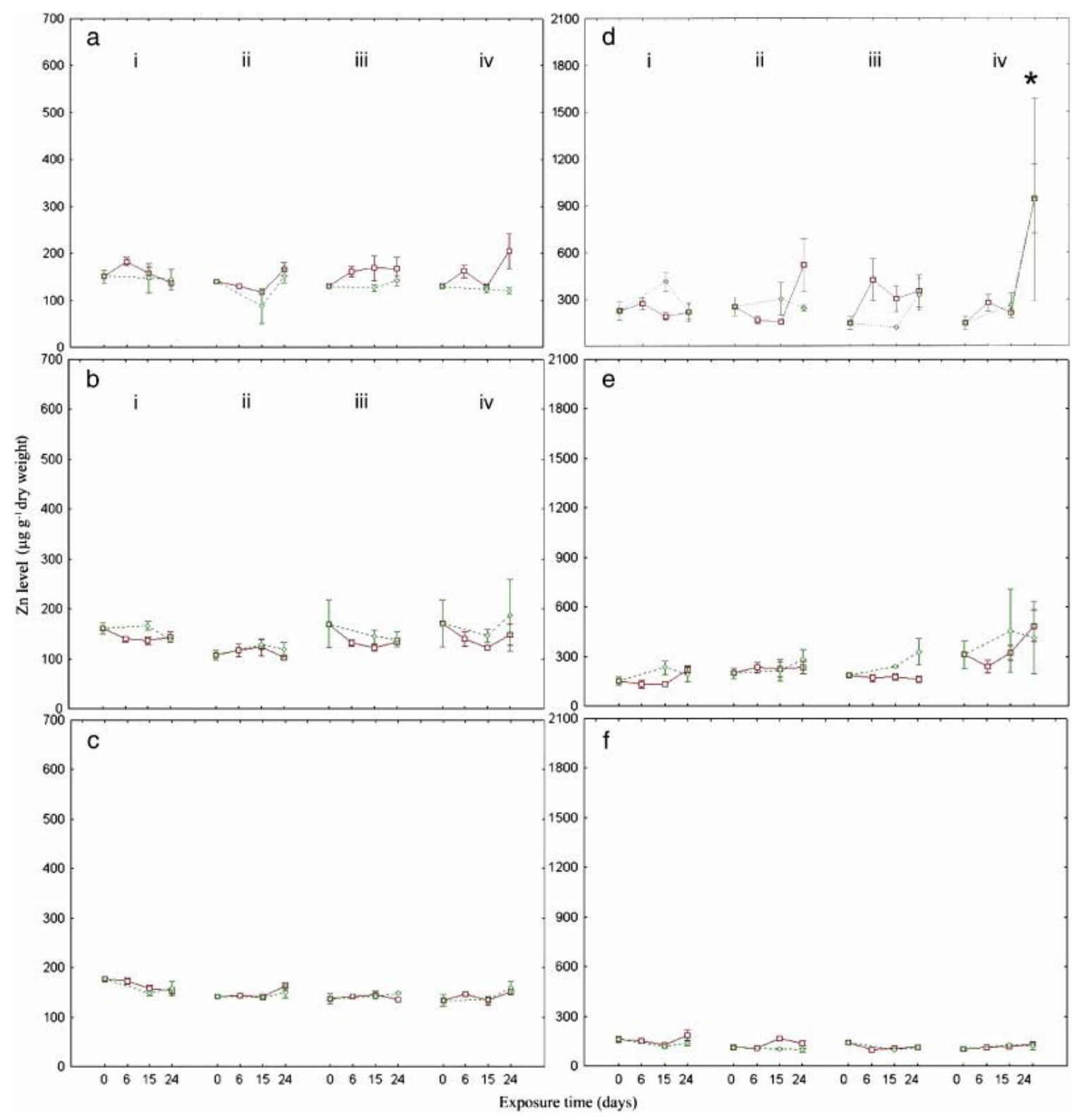

Fig. 3.

Mean variation of Zn levels ( $\mu \mathrm{g} \mathrm{g}^{-1}$, dry mass) in the gills (a-b-c) and digestive gland (d-e-f) of control (dashed lines) and exposed mussels (solid lines) at each experiment (i, ii, iii, and iv) for 24 days. 


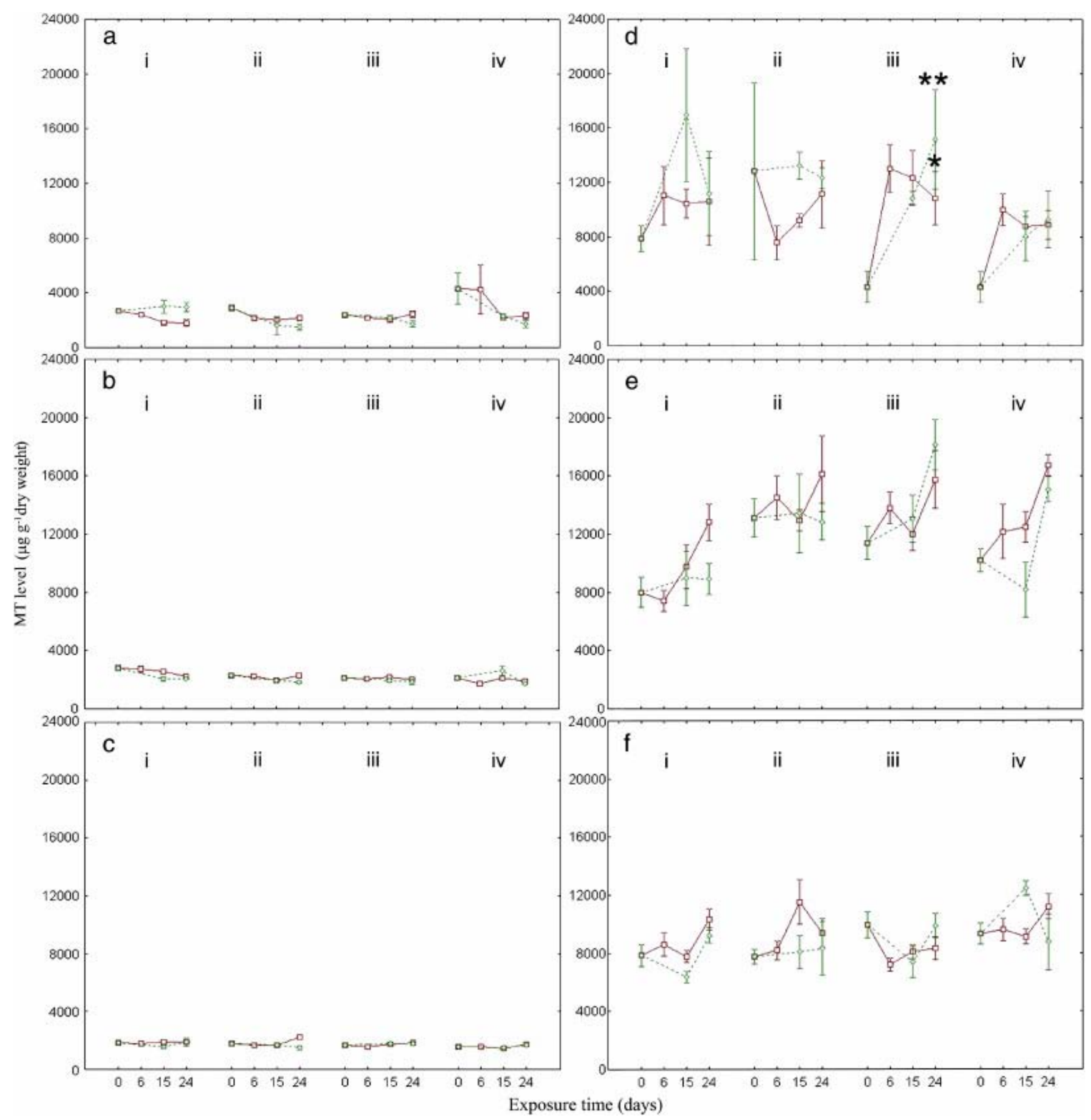

Fig. 4.

Mean variation of MT levels ( $\mu \mathrm{g} \mathrm{g}^{-1}$, dry mass) in the gills (a-b-c) and digestive gland (d-e-f) of control (dashed lines) and exposed mussels (solid lines) at each experiment (i, ii, iii, and iv) for 24 days. 


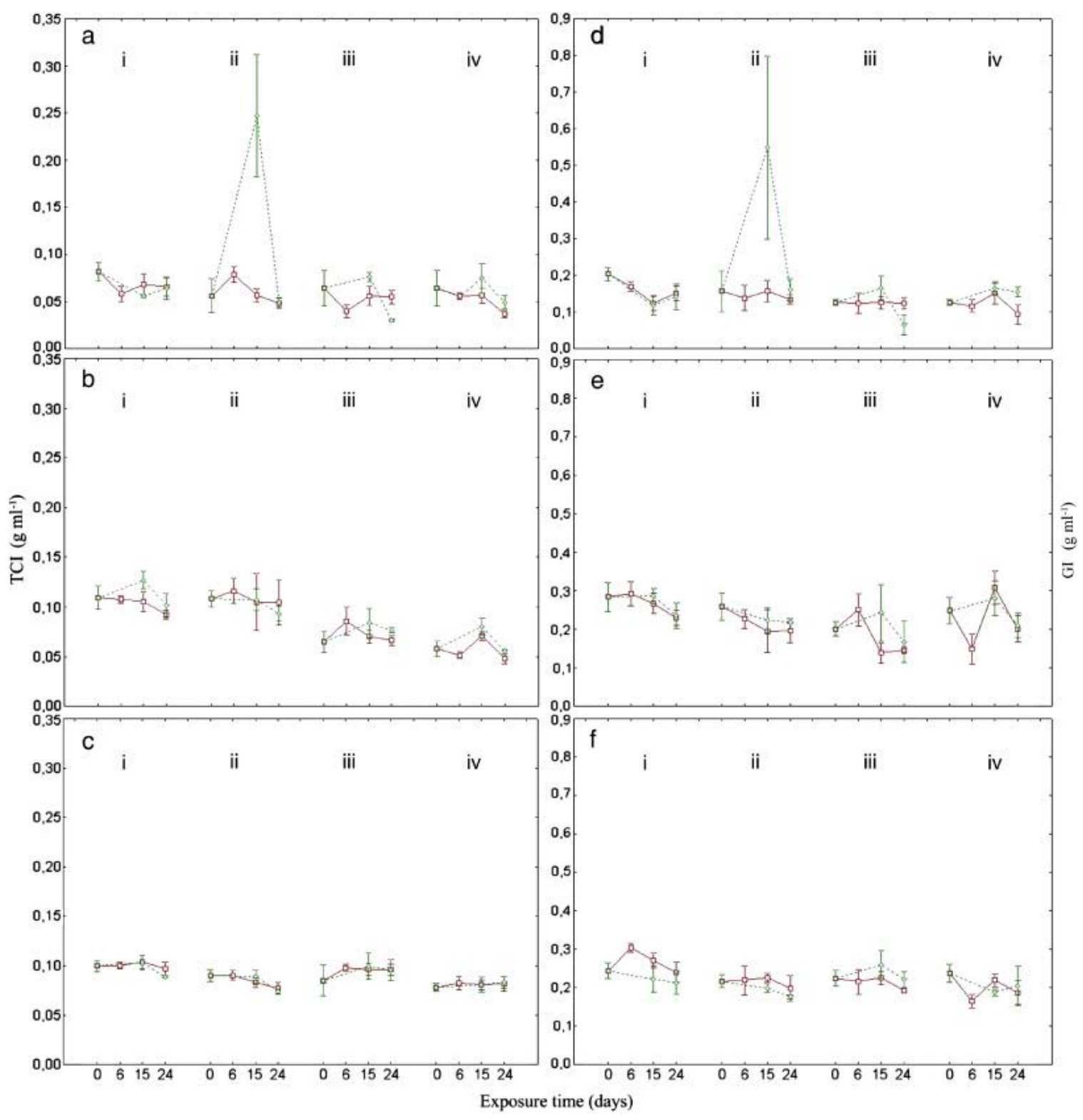

Fig. 5. Mean variation $\left(g \mathrm{~mL}^{-1}\right)$ of $\mathrm{TCl}(\mathrm{a}-\mathrm{b}-\mathrm{c})$ and $\mathrm{GCl}(\mathrm{d}-\mathrm{e}-\mathrm{f})$ of control (dashed lines) and exposed mussels (solid lines) at each experiment (i, ii, iii, and iv) for 24 days. 


\section{Protocol (i)}
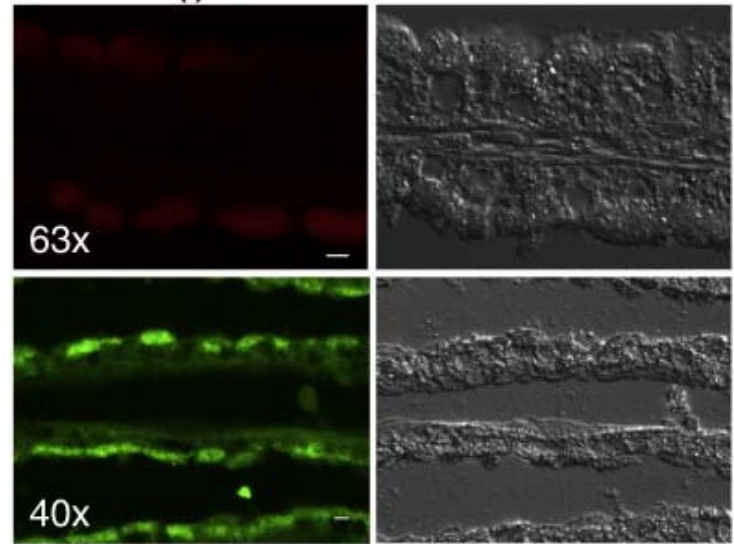

A1
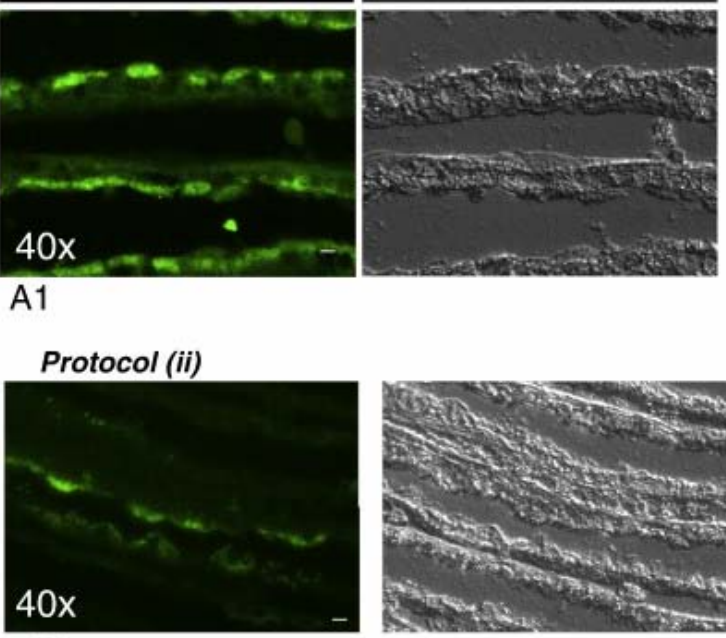

B1

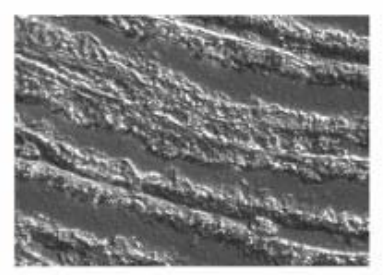

protocol (iii) and (iv)
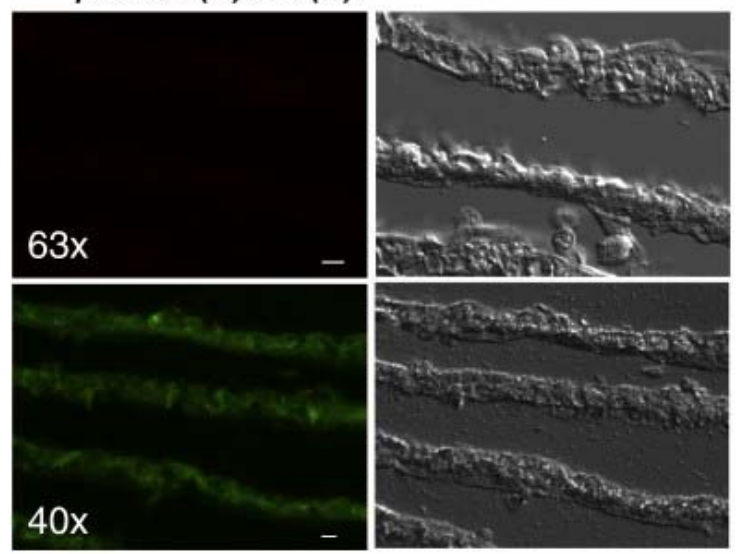

C1
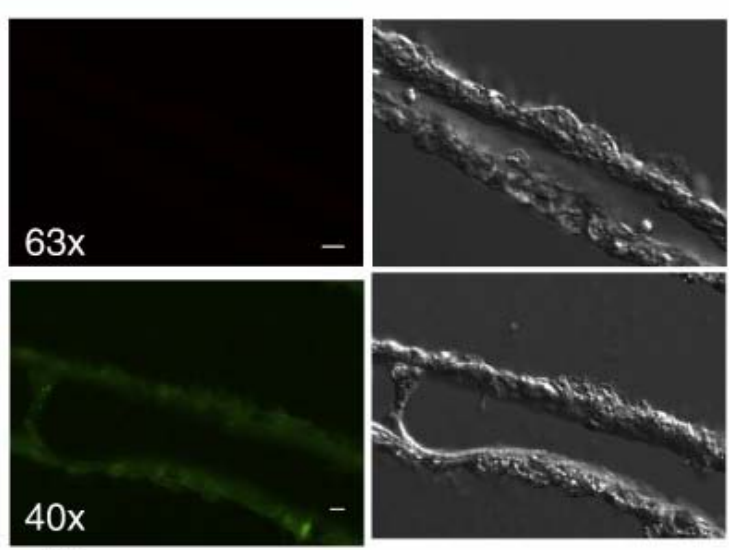

A2

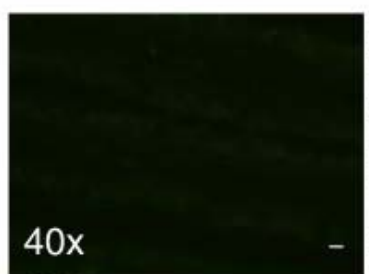

B2
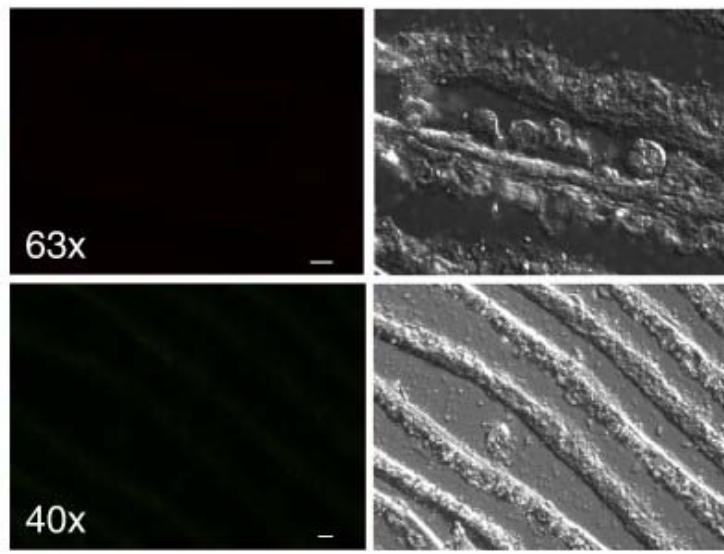

$40 x$

C2

Fig. 6. Detection of thiotrophic and methanotrophic bacterial endosymbionts in gill tissue. Fluorescent probes were used to target thiotrophic (red) and methanotrophic (green) bacterial symbionts in fluorescence in situ hybridization (FISH) experiments. Differential interference contrast (DIC) visualization is shown (right side of panels). Scale bar $(10 \mu \mathrm{m})$ and original objective magnifications are indicated. Panel A shows the density of both bacteria at day 0 (A1) and day 24 (A2) of exposure for experiment (i). Panel B shows the methanotrophic bacteria density at day 0 (B1) and day 24 (B2) of exposure for experiment (ii). Panel $C$ shows the density of both bacteria at day 0 (C1) and day 24 (C2) of exposure for experiments (iii) and (iv). 